\title{
Knowledge and Severity of Female Urinary Incontinence and Reasons for Not Seeking Treatment
}

\author{
Hadi Susiarno, Ryandra Prakarsa Tryastama, Budi Handono \\ Department of Obstetrics and Gynecology Faculty of Medicine Universitas Padjadjaran \\ Dr. Hasan Sadikin General Hospital Bandung, Indonesia
}

\begin{abstract}
Urinary incontinence (UI) is a commonly overlooked problem in women, particularly women of post-menopausal age. Despite the medical, social, and hygiene burdens conferred by UI to its sufferers, past studies have shown that only a few among women afflicted with UI sought treatment. This may be due to various reasons: lack of knowledge and awareness of UI or a wrong belief of UI as a natural part of aging. This study aimed to investigate the association between knowledge and severity of UI and reasons for not seeking treatment among postmenopausal women in Bandung, Indonesia. This was an analytic cross-sectional study conducted at the Geriatric and Gynecology Clinic, Dr. Hasan Sadikin General Hospital, in September 2013. Ninety-one women who met the inclusion criteria were interviewed to assess their knowledge of UI. The severity of UI was assessed using Urinary Distress Inventory 6 (UDI-6). Data were analyzed using the chi-square test. Sixty-five respondents (70.7\%) had poor knowledge of UI. Knowledge of UI was not associated with awareness of UI as a medical condition $(p=0.633)$. The difference in UI severity was associated with the perception of UI as a normal part of aging $(p=0.008)$. Postmenopausal women are poorly informed regarding urinary incontinence. However, knowledge alone might not be adequate to encourage women to seek treatment. Further studies are needed to investigate women's reasons for not seeking treatment for UI.
\end{abstract}

Keywords: Knowledge, treatment-seeking, urinary incontinence

\section{Hubungan Pengetahuan dan Derajat Keparahan Inkontinensia Urin Wanita dan Alasan Tidak Melakukan Pengobatan}

\begin{abstract}
Abstrak
Inkontinensia urin (IU) adalah masalah yang sering tidak tertangani pada wanita. Meskipun terdapat beban medis, sosial, serta higienitas pribadi yang diakibatkan oleh IU, penelitian menunjukkan bahwa hanya sedikit wanita dengan IU mencari pertolongan medis. Penelitian ini menelaah hubungan pengetahuan dan derajat keparahan IU serta alasan tidak berobat pada wanita yang melaporkan IU tapi tidak berobat di Bandung, Indonesia. Penelitian ini adalah penelitian observasional analitik potong lintang yang dilakukan di klinik Geriatri dan Ginekologi Rumah Sakit Dr Hasan Sadikin, Bandung, Indonesia pada September 2013. Sembilan puluh satu wanita yang memenuhi kriteria inklusi diwawancara untuk menganalisis pengetahuan tentang IU. Derajat keparahan IU dinilai menggunakan Urinary Distress Knowledge 6 (UDI-6). Data dianalisis menggunakan uji chi-square. Enam puluh lima responden $(70,7 \%)$ memiliki pengetahuan rendah terhadap IU. Pengetahuan IU tidak berhubungan dengan kesadaran IU sebagai kondisi medis $(\mathrm{p}=0,633)$. Terdapat perbedaan persepsi tentang IU sebagai kondisi normal diantara wanita dengan derajat keparahan IU yang berbeda $(p=0,008)$. Wanita pasca-menopause belum memiliki pengetahuan yang baik mengenai IU. Meskipun demikian, pengetahuan yang cukup belum tentu mampu mendorong wanita mencari pertolongan medis. Penelitian lanjutan dibutuhkan untuk menelaah lebih jauh alasan wanita dengan IU tidak mencari pertolongan medis.
\end{abstract}

Kata kunci: Inkontinensia urin, melakukan pengobatan, pengetahuan

Corresponding Author: Hadi Susiarno, Department of Obstetrics and Gynecology Faculty of Medicine Universitas Padjadjaran/ Dr. Hasan Sadikin General Hospital, Jalan Pasteur No. 38 Bandung, West Java, Indonesia, Email: drhadi.susiarno@yahoo.com 


\section{Introduction}

Urinary incontinence (UI) has been defined by the International Continence Society as involuntary leakage of urine. ${ }^{1}$ In women, the prevalence rate of UI is estimated to be around 10-58\% globally, with the Asia Pacific Continence Advisory Board estimating the prevalence among Asian women to be around $14.6 \%{ }^{1}$. The exact prevalence of urinary incontinence among Indonesian women is currently unknown, despite the estimates that range between $14 \%$ based on a study conducted in 2017 to $30-40 \%$ in a study by Surjadi et al. ${ }^{2}$ This uncertain prevalence is due to various factors: differences in working definition of incontinence; sample population, and methodology. ${ }^{3-5}$

Urinary incontinence is diagnosed across all stages of life; however, the incidence and severity tend to increase with age. The prevalence among girls and young women aged 15 to 34 is around $10 \%$, which increases to $12 \%$ among women aged $35-65$, and as high as $16 \%$ among women older than 65 years old. ${ }^{2}$

A history of vaginal childbirth and menopause has been suggested as contributing factors to the incidence of urinary incontinence in middle- to advanced-aged women. UI is more commonly observed among parous women compared to nulliparous women, and the prevalence increases along with increasing parity. ${ }^{5}$

In addition to the personal toll faced by its sufferers, UI also create a considerable economic burden for the country where they live. The cost for UI in Sweden and the United States is estimated to be $2 \%$ of the annual health-care budget. ${ }^{1}$ Despite the burdens associated with UI, only a small number of women afflicted with UI sought treatment. In a multi-center, multiracial, and multi-disciplinary study of women undergoing menopausal transition, sixty-one percent of women who reported UI also reported that they do not seek treatment. ${ }^{6}$ Findings in Denmark also echo a similar result with only $25.1 \%$ of 1.063 women who reported UI consult a physician. Similarly, in Germany, only $31.4 \%$ of 786 German women with UI seek treatment. ${ }^{7}$ Previous studies have suggested that there are cultural factors that hinder women with UI to seek treatment: a misleading belief that UI is normal among women of advanced age, or social discomfort and shame associated to admitting UI, which exacerbate the impacts of UI on patients' physical and mental well-being., 6,8

With this in mind, this study sought to assess the knowledge and severity of UI among Indonesian women who reported UI but did not directly seek medical treatment for UI. In an attempt to understand why these women did not seek treatment, this study also tried to udnerstand the association between knowledge and severity of UI and the perception of UI as a normal part of aging in women, or that UI could resolve on its own.

\section{Methods}

The protocol for this study was approved by the Health Reseacrh Ethics Committee for Medical Research Universitas Padjadjaran, under the registration number of 208/UN6.C2.1.2/KEPK/ PN/2013.

This study was an analytic observational cross-sectional study involving post-menopausal women diagnosed with urinary incontinence but sought medical treatment for other medical conditions. The sample size was pre-determined using Cochran's sample size formula, with $\alpha=5 \%$. Samples were recruited using the purposive sampling technique according to the inclusion criteria until the predetermined sample size was reached.

The inclusion criteria used in this study were: post-menopausal women; diagnosed with UI but did not seek medical treatment; and agreed to be recruited to the study. Sampled participants were interviewed on their knowledge of urinary incontinence using a questionnaire and scoring was applied to the results. The knowledge was categorized as 'Poor' and 'Proficient' based on a threshold of $(\mathrm{x})<$ mean $-1 \mathrm{SD}$ and $(\mathrm{x})>$ mean + $1 \mathrm{SD}$, respectively. The degree of severity of the incontinence was assessed using the Urinary Distress Inventory 6 (UDI-6) questionnaire and re-classified into "Mild" (0- $\leq 33)$, "Moderate" ( $>33-\leq 67)$ and "Severe" (>67 to100).

Data were collected and recorded using SPSS 21.0 for Windows. Descriptive statistics were computed for subject baseline characteristics, whereas the level of knowledge, degree of severity, and attitude were computed using Chisquare test.

\section{Results}

Recruitment of the subjects began in September 2013 in the Geriatric and Gynecology Clinic of Dr Hasan Sadikin General Hospital, Bandung, Indonesia. Ninety-one subjects who met the inclusion criteria were enrolled after giving verbal and written consent. Baseline characteristics of 
H Susiarno et al: Knowledge and Severity of Female Urinary Incontinence and Reasons for Not Seeking Treatment

Table 1 Baseline Characteristics

\begin{tabular}{|c|c|c|c|}
\hline \multirow{2}{*}{ Characteristics } & \multicolumn{2}{|c|}{ Value (\%) } & \multirow{2}{*}{ Mean \pm SD } \\
\hline & $\mathbf{N}$ & $\%$ & \\
\hline Age & 91 & 100 & $59.3736 \pm 9.30071$ \\
\hline \multicolumn{4}{|l|}{ Occupation } \\
\hline Stay at-home & 59 & 64.8 & \\
\hline Agricultural labor & 1 & 1.1 & \\
\hline Farmer & 1 & 1.1 & \\
\hline Laborer & 0 & 0 & \\
\hline Trader & 2 & 2.2 & \\
\hline Salarywoman & 1 & 1.1 & \\
\hline Civil service/Military & 23 & 25.3 & \\
\hline Others & 4 & 4.4 & \\
\hline \multicolumn{4}{|l|}{ Education } \\
\hline Primary school & 26 & 28.5 & \\
\hline Middle school & 14 & 15.4 & \\
\hline High school & 20 & 22.0 & \\
\hline Tertiary & 31 & 34.1 & \\
\hline \multicolumn{4}{|l|}{ Income (monthly, in IDR) } \\
\hline$<500,000$ & 7 & 7.7 & \\
\hline IDR500,000- < 1 million & 23 & 25.3 & \\
\hline $1-<2$ million & 19 & 20.9 & \\
\hline $2-<3$ million & 13 & 14.3 & \\
\hline$>3$ million & 29 & 31.9 & \\
\hline
\end{tabular}

Table 2 Attitude on Urinary Incontinence by Knowledge Level

\begin{tabular}{|c|c|c|c|c|}
\hline & \multicolumn{2}{|c|}{ Knowledge Level } & \multirow{2}{*}{ Total } & \\
\hline & Poor & Proficient & & \\
\hline \multirow{2}{*}{\multicolumn{4}{|c|}{$\begin{array}{l}\text { Attitude } \\
\text { "Urinary incontinence is a normal part of aging." }\end{array}$}} & \multirow[t]{2}{*}{ p-value } \\
\hline & & & & \\
\hline Yes & 41 & 15 & 56 & $0.633^{\dagger}$ \\
\hline No & 24 & 11 & 35 & \\
\hline \multicolumn{5}{|c|}{ "Urinary incontinence will resolve on its own." } \\
\hline Yes & 15 & 11 & 26 & \multirow[t]{2}{*}{$0.067^{\dagger}$} \\
\hline No & 50 & 15 & 65 & \\
\hline
\end{tabular}

Table 3 Attitude on Urinary Incontinence by Incontinence Severity

\begin{tabular}{|c|c|c|c|c|c|}
\hline & \multicolumn{3}{|c|}{ Severity } & \multirow{2}{*}{ Total } & \\
\hline & Mild & Moderate & Severe & & \\
\hline \multicolumn{4}{|c|}{$\begin{array}{l}\text { Attitude } \\
\text { "Urinary incontinence is a normal part of aging." }\end{array}$} & \multicolumn{2}{|r|}{ p-value } \\
\hline Yes & 41 (75.9\%) & $13(39.4 \%)$ & $2(50 \%)$ & 56 & $0.008^{\dagger}$ \\
\hline No & $13(24.1 \%)$ & $20(60.6 \%)$ & $2(50 \%)$ & 35 & \\
\hline \multicolumn{6}{|c|}{ "Urinary incontinence will resolve on its own." } \\
\hline Yes & $12(22.2 \%)$ & $13(39.4 \%)$ & $1(25 \%)$ & 16 & $0.225^{\dagger}$ \\
\hline No & $42(77.8 \%)$ & $20(60.6 \%)$ & $3(75 \%)$ & 65 & \\
\hline
\end{tabular}

${ }^{\dagger}$ Chi-square test, significance determined at $p<0.05$ 


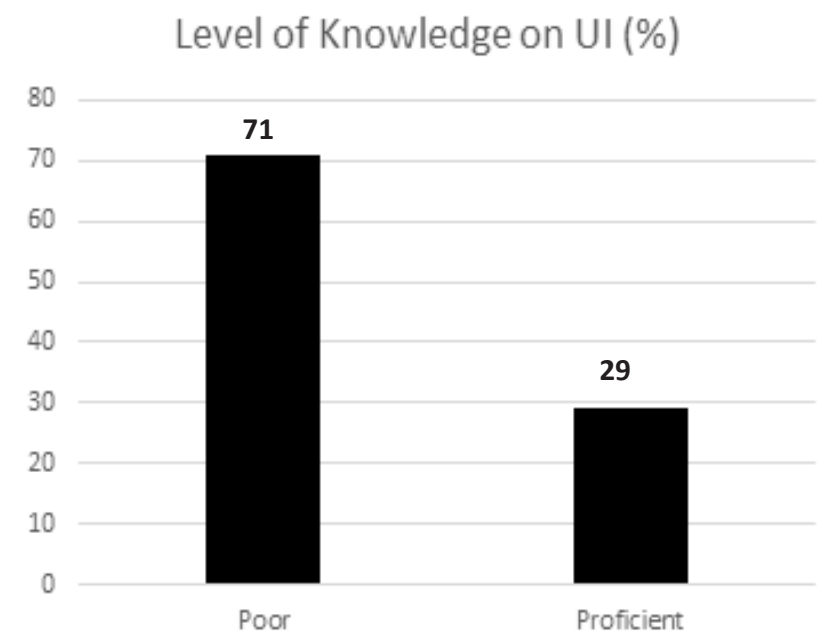

Figure Knowledge of UI

the subjects are presented in Table 1.

of the ninety-one participants in this study, sixty-five $(70.7 \%)$ had poor knowledge level of urinary incontinence (Figure). There was no significant difference between groups with poor knowledge level and those with proficient knowledge in their attitude towards urinary incontinence, with 41 and 15 women with poor and proficient knowledge, respectively, saw urinary incontinence as a 'normal' issue, whereas 24 and 11 of women with poor and proficient knowledge of urinary incontinence, respectively, did not (Table 2).

There was, however, a clear difference seen in the attitude of women with different urinary incontinence severity, While most of our samples $(61 \%)$ answered that urinary incontinence is "a normal issue," this result might be influenced by the overwhelming number of women with mild urinary incontinence in our sample compared to women with moderate and severe incontinence (Table 3). Interestingly, the majority of our samples opined that urinary incontinence could not resolve on its own regardless of the degree of severity.

\section{Discussion}

This study showed that among post-menopausal women who reported UI but chose not to seek treatment in Bandung, Indonesia, most of them (71\%) lack proper awareness and knowledge of UI. Among our respondents, merely $21 \%$ had a proficient level of knowledge on UI. These estimates are similar to the results of previous studies overseas by Chen et al., who found that $72 \%$ of their 346 female respondents have nonproficient level of knowledge regarding UI. ${ }^{7}$

It is interesting to note that Chen identified several demographic factors, such as age, AfroAmerican race, income, and lower education, to be significantly associated with UI knowledge non-proficiency. ${ }^{7}$ In Chen's study, self-reported lack of awareness of UI as a medical condition was the greatest predictor of UI knowledge non-proficiency, despite the fact that a similar effect was seen with educational attainment. ${ }^{8}$ The small sample size in this study did not allow analyses of associations between UI knowledge and demographic factors; however, our samples' educational achievements were quite evenly distributed, and $34.1 \%$ of our respondents had completed their high school diploma, while only $21 \%$ were proficient in their knowledge of UI.

Knowledge of UI was not associated with the awareness of UI as a medical condition in the present study $(\mathrm{p}=0.633)$. This misconception of UI as a consequence of normal female childbirth and aging have been demonstrated by a number of authors across cultures. ${ }^{4,8-10}$

There was a clear difference in attitude on the normalcy of UI among women with different UI severity $(p=0.008)$. However, this result may be influenced by the number of women who reported only mild UI, as they make up the large part of participants who answered that urinary incontinence is a normal part of 
aging $(75.9 \%)$ whereas our respondents who reported moderate and severe UI appeared to be somewhat more aware of the UI status as a medical problem. This may suggest that with the increased quality of life, the disruption brought by increased severity may make women to be more aware that UI is a medical condition. Why these respondents did not seek treatment, however, is unknown and merits further studies.

Most of the participants believed that UI will not resolve on its own. Fatalistic beliefs in women regarding the function of their body as they age, especially their bladder, have been noted previously by Basu and Duckett. This ties again to the belief that the bladder "weakens" as women grow older, and incontinence is merely a common phenomenon to be endured. ${ }^{8}$ The respondents in Basu's study do not seek treatment because they believe that UI treatment for older women is less effective owing to their age. ${ }^{8}$

The findings of the current study could be used as the basis for designing the educational programs for Indonesian women affected by UI. However, its power is limited by the small sample size and limited demographic distribution. Further research with a larger sample size is necessary to investigate the link between socioeconomic status, educational attainment, and knowledge and awareness of UI, if any, as well as in-depth qualitative research investigating women's beliefs regarding aging, UI, and the role of medical treatment in managing UI.

In conclusion, post-menopausal women are poorly informed regarding UI. Clinicians caring for post-menopausal women at greater risk of UI should carefully assess their patients' knowledge and awareness of this medical condition and offer treatment where applicable.

\section{References}

1. Milsom I, Gyhagen M. The prevalence of urinary incontinence. Climacteric. 2019;22(3):217-22.

2. Surjadi LM, Purwara BH. Tinjauan dugaan inkontinensia urin pada penderita yang datang ke poliklinik ginekologi RS. Hasan Sadikin Bandung. JIMK. 2017;5(1):75-81.

3. Cardozo L, Staskin D. Textbook of Female Urology and Urogynaecology. $1^{\text {st }}$ ed. United States: CRC Press; 2016.

4. Perera J, Kirthinanda DS, Wijeratne S, Wickramarachchi TK. Descriptive cross sectional study on prevalence, perceptions, predisposing factors and health seeking behaviour of women with stress urinary incontinence. BMC Womens Health. 2014;14:78.

5. Waetjen LE, Xing G, Johnson WO, Melnikow J, Gold EB. Factors associated with seeking treatment for urinary incontinence during the menopausal transition. Obstet Gynecol. 2015;125(5):1071-9.

6. Schreiber Pedersen L, Lose G, Høybye MT, Jürgensen $M$, Waldmann A, Rudnicki M. Predictors and reasons for helpseeking behavior among women with urinary incontinence. Int Urogynecol J. 2018;29(4):521-30.

7. Chen CCG, Cox JT, Yuan C, Thomaier L, Dutta S. Knowledge of pelvic floor disorders in women seeking primary care: A cross-sectional study. BMC Fam Pract. 2019;20(1):70.

8. Basu M, Duckett J. Barriers to seeking treatment for women with persistent or recurrent symptoms in urogynaecology. BJOG. 2009;116(5):726-30.

9. Fritel X, Panjo H, Varnoux N, Ringa V. The individual determinants of care-seeking among middle-aged women reporting urinary incontinence: Analysis of a 2273-woman cohort. Neurourol Urodyn. 2014;33(7):1116-22.

10. Choi H, Park JY, Yeo JK, Oh MM, Moon DG, Lee JG, et al. Population-based survey on disease insight, quality of life, and healthseeking behavior associated with female urinary incontinence. Int Neurourol J. 2015;19(1):39-46. 